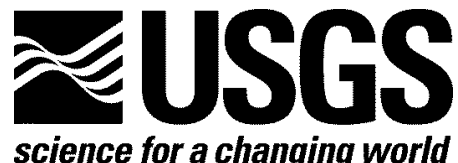

science for a changing world

\title{
Principal Facts of Gravity data in the Northern Willamette Valley and Vicinity, Northwestern Oregon and Southwestern Washington
}

By Robert L. Morin, Karen L. Wheeler, Darcy K. McPhee, Philip A. Dinterman, and Janet T. Watt

Open-File Report 2007-1058

U.S. Department of the Interior

U.S. Geological Survey 


\section{U.S. Department of the Interior \\ DIRK A. KEMPTHORNE, Secretary}

\section{U.S. Geological Survey \\ Mark D. Myers, Director}

U.S. Geological Survey, Reston, Virginia 2007

For product and ordering information:

World Wide Web: http://www.usgs.gov/pubprod

Telephone: 1-888-ASK-USGS

For more information on the USGS-the Federal source for science about the Earth,

its natural and living resources, natural hazards, and the environment:

World Wide Web: http://www.usgs.gov

Telephone: 1-888-ASK-USGS

Any use of trade, product, or firm names is for descriptive purposes only and does not imply endorsement by the U.S. Government.

Although this report is in the public domain, permission must be secured from the individual copyright owners to reproduce any copyrighted material contained within this report. 


\section{Contents}

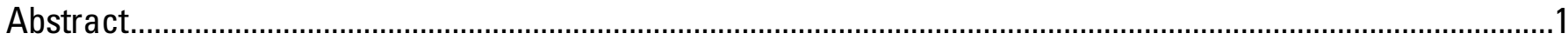

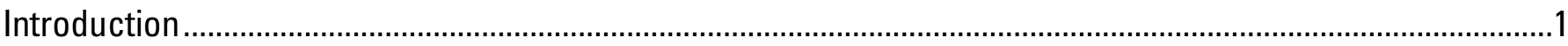

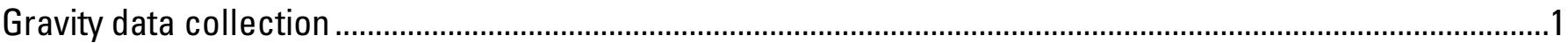

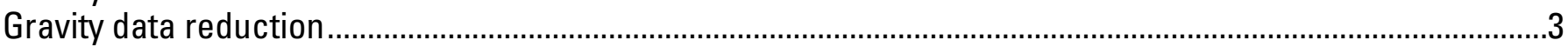

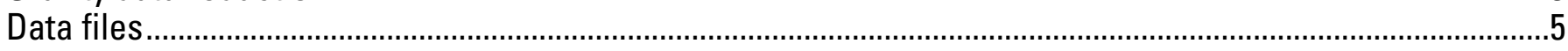

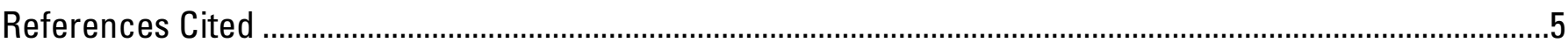

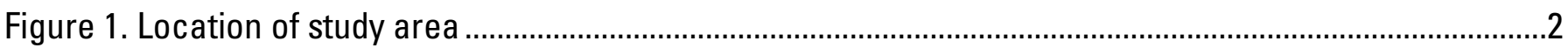

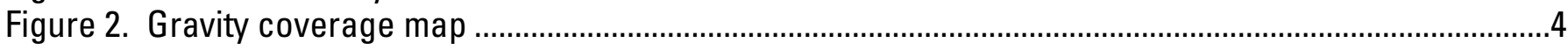




\title{
Principal Facts of Gravity data in the Northern Willamette Valley and Vicinity, Northwestern Oregon and Southwestern Washington
}

\author{
By Robert L. Morin, Karen L. Wheeler, Darcy K. McPhee, Philip A. Dinterman, and Janet T. Watt
}

\begin{abstract}
Gravity data were collected from 2004 through 2006 to assist in mapping subsurface geology in the northern Willamette Valley and vicinity, northwestern Oregon and southwestern Washington. Prior to this effort to improve the gravity data coverage in the study area, very little regional data were available. This report gives the principle facts for 2710 new gravity stations and 1446 preexisting gravity stations. Much of the study area is now covered with data of sufficient density to define basin boundaries and correlate with many of the larger fault systems.
\end{abstract}

\section{Introduction}

The study area (fig. 1) lies between $44^{\circ} 52.5^{\prime}$ and $46^{\circ} \mathrm{N}$ latitude and between $122^{\circ} 15^{\prime}$ and $123^{\circ}$ $37.5^{\prime} \mathrm{W}$ longitude. Although this is a continuing project and more gravity data is expected to be collected, this report is being published to show the progress of the data collection. The majority of these data are spaced at about $1.6 \mathrm{~km}$ ( 1 mile), but three closely spaced profiles were measured in the Portland area across several faults. To obtain a $1.6 \mathrm{~km}$ grid of data points would require about 5120 gravity stations. To date we have collected 2710 stations. Including the preexisting data points, the total number of stations is 4156 , and complete regional coverage is about $80 \%$ at this time.

\section{Gravity data collection}

Gravity data for this study were collected with a LaCoste and Romberg G-model gravity meter and measurements were recorded to $0.001 \mathrm{mGal}$. Most of the data were collected along roadways, where station locations were determined by attempting to space them in a $1.6 \mathrm{~km}$ (1 mile) grid. Much of the flatter parts of the study area have roads along sections lines which run east-west and north-south at one mile spacing where feasible. This makes it possible to collect gravity data at a one-mile grid in most cases, which is a good spacing for regional data. In the mountainous areas, this grid was continued as best we could. The detailed surveys in the Portland area typically have station spacing of $0.3 \mathrm{~km}(0.2$ miles). Precise locations and elevations were made with a Trimble GeoXT GPS, which are later processed through publicly accessible websites that produce elevations that claim to be sub-meter in accuracy.

Several gravity base stations were used for these surveys. The three main bases were located in Portland (R14), McMinnville (4611-1), and Oregon City (OCBA). The OCBA base in Oregon City appeared to be physically altered, so multiple ties were made to R14 and a new observed gravity value was established. Multiple ties from the main three bases established the other bases used. The other bases are located in Newberg (NEWT), Forest Grove (FORT), St. Helens (STHB), and Troutdale (TROB). 


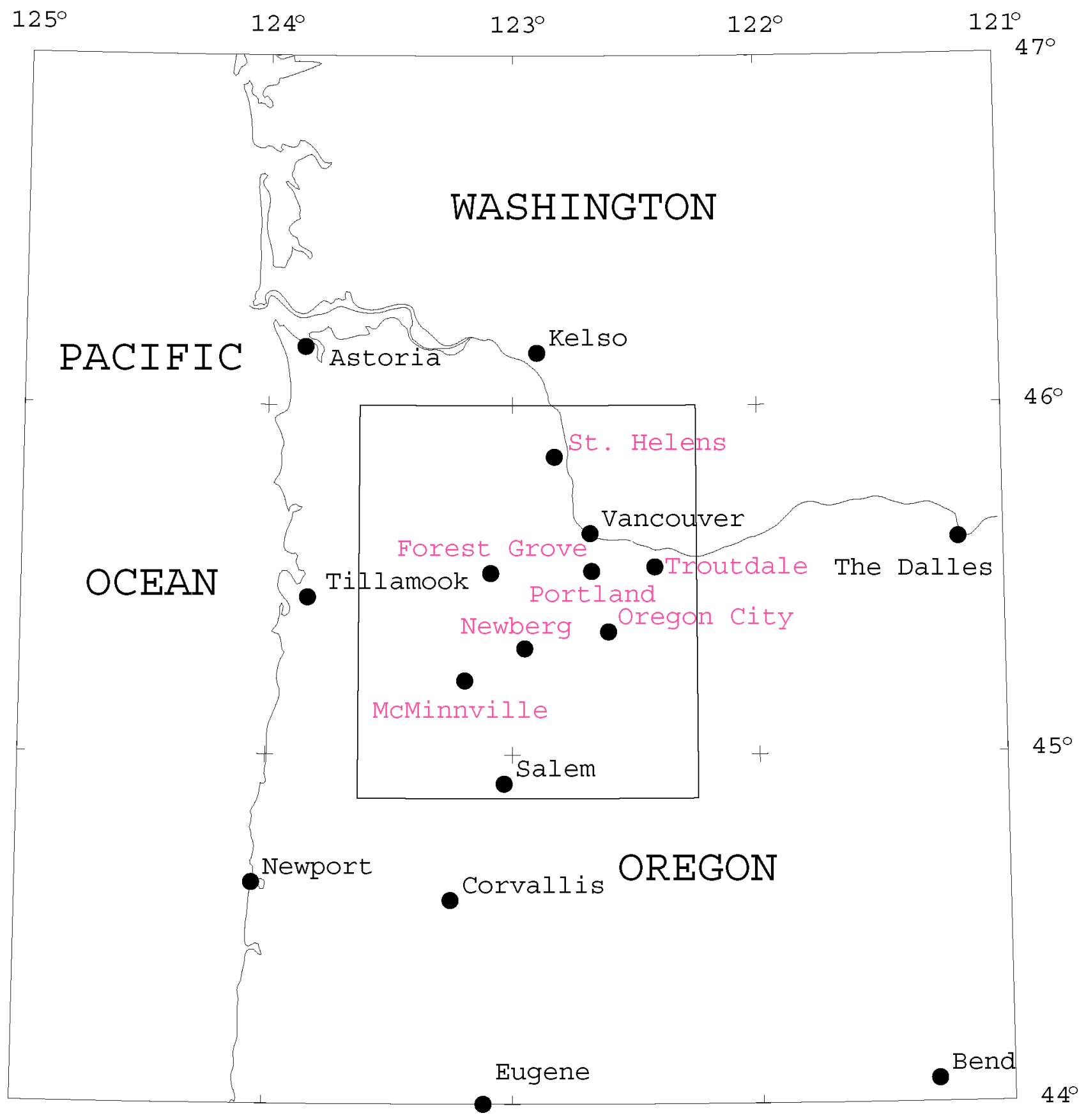

Figure 1. Index map of study area. The rectangle in the center of the figure is the outline of the study area. Selected place names are for reference. Cities that are printed in red are those that have gravity base stations that were used in this study. 
The naming convention used for these secondary bases was a four-letter name, with the first three letters being an abbreviation of the city and the fourth letter representing a location within that city. In these cases, the $\mathrm{T}$ is for Travelodge and the $\mathrm{B}$ is for Best Western. The principal facts for these base stations are listed in the Data files section below. A base station was read at the beginning and end of each survey session and checked at the close of each session for excess meter drift or tares using prepared tables of earth tide, which are applied to the base readings.

The current status of the gravity coverage in the study area is shown in figure 2 . The grid lines shown on the figure are the boundaries of the 7.5' U.S. Geological Survey (USGS) topographic quadrangles. The coverage that we were attempting to obtain, a $1.6 \mathrm{~km}$ grid, requires from 50 to 60 stations per quadrangle. When the project was started, many of the quadrangles had fewer than five gravity stations, some with no gravity stations. There are still many quadrangles with fewer than five gravity stations. Of the 99 quadrangles in the study area, about 50 are complete, and about five additional quadrangles are nearly complete.

\section{Gravity data reduction}

Conversion to milligals is made using factory calibration constants and a calibration factor, which varies with each gravity meter and has been determined by multiple gravity readings over the Mt. Hamilton calibration loop east of San Jose, CA (Barnes and others, 1969). Observed gravity values are based on an assumed linear drift between successive base readings. Small portable differential GPS units mostly provide vertical and horizontal control.

Three levels of terrain corrections were made based on the method of Hayford and Bowie (1912). Field terrain corrections are made in the field by calculating the effect of the local terrain from the station to a radial distance of $68 \mathrm{~m}$. Inner terrain corrections from a radial distance of $68 \mathrm{~m}$ to a radial distance of 2.0 $\mathrm{km}$ are calculated using $10 \mathrm{~m}$ digital elevation models (DEMs). Outer terrain corrections are computed from a radial distance of $2.0 \mathrm{~km}$ from the station to a radial distance of $166.7 \mathrm{~km}$ with a FORTRAN program (Plouff, 1977) and a digital terrain model. These data are processed through an isostatic reduction program (Jachens and Roberts, 1981) in order to suppress the effects of deep density distributions that buoyantly support the topography. The isostatic reduction assumes an Airy-Heiskanen model with the following parameters from the station to $166.7 \mathrm{~km}$ : density of topography above sea level, $2.67 \mathrm{~g} / \mathrm{cm}^{3}$; crustal thickness at sea level, $25 \mathrm{~km}$; and density contrast across the base of the model crust, $0.4 \mathrm{~g} / \mathrm{cm}^{3}$. From a radial distance of $166.7 \mathrm{~km}$ from the station to a point on the opposite side of the Earth, isostatic and terrain corrections are taken off maps by Karki and others (1961). These corrections are added to the output of the isostatic program of Jachens and Roberts (1981) to produce the isostatic correction.

Theoretical gravity at sea level is based on the Geodetic Reference System 1967 (GRS 67) (International Association of Geodesy, 1971, p. 58) for the shape of the spheroid. The datum for the observed gravity is the International Gravity Standardization Net 1971 (IGSN 71) (Morelli, 1974. p. 18).

Observed gravity values are calculated by adding meter drift and earth-tide corrections to the milligal equivalent meter readings. Free-air anomalies are calculated by subtracting the theoretical gravity from the observed gravity and adding the free-air correction as defined by Swick (1942, p. 65). Simple Bouguer anomalies are calculated by subtracting the Bouguer correction, which accounts for the attraction of rocks between the station and sea level using a rock density of $2.67 \mathrm{~g} / \mathrm{cm}^{3}$ from the free-air anomaly. Complete Bouguer anomalies are calculated by adding the terrain correction and the curvature correction to the simple Bouguer anomaly. Isostatic anomalies are calculated by adding the isostatic correction to the complete Bouguer anomaly. 


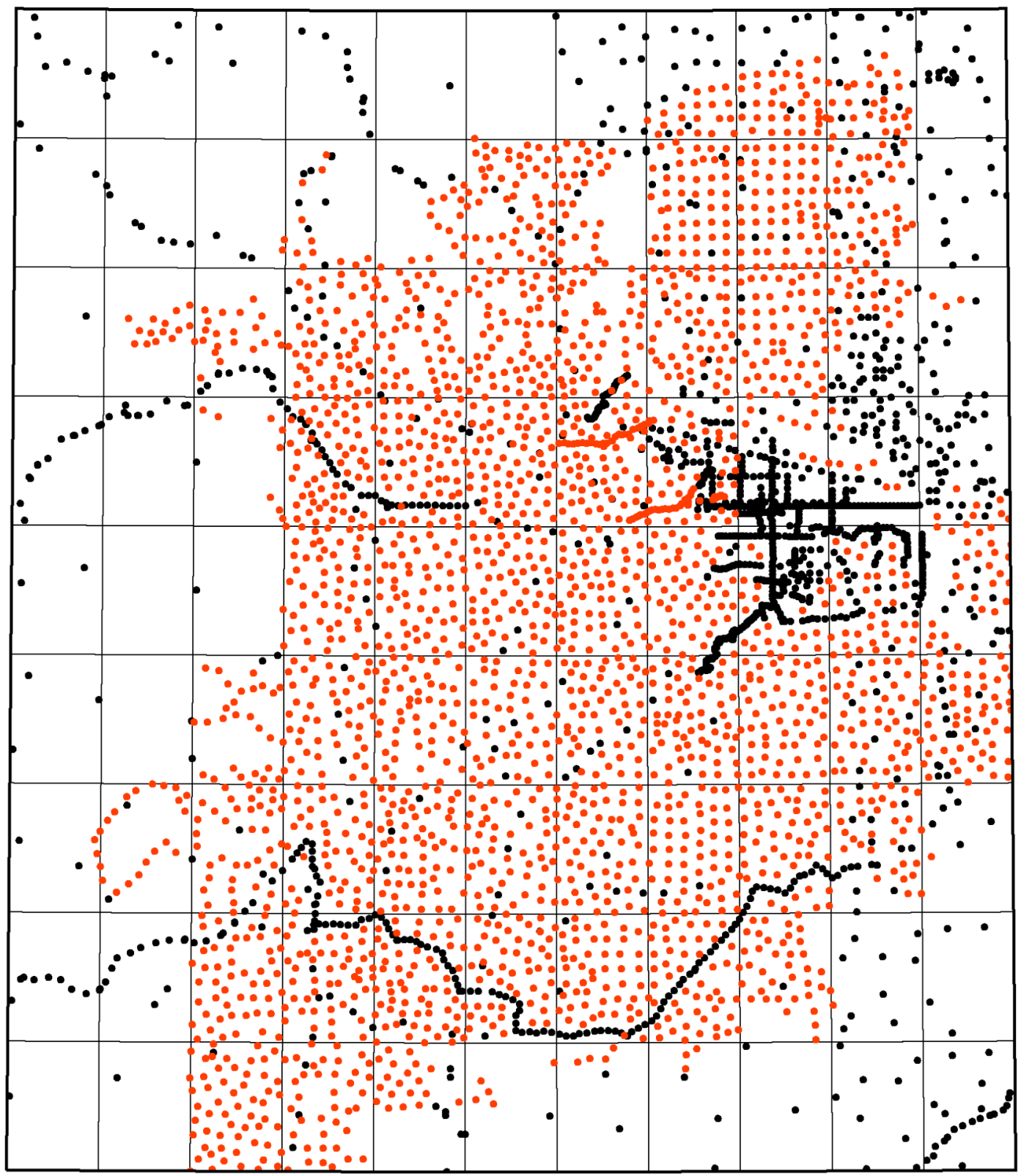

$\begin{array}{lllllll}0 & 10 & 20 & 30 & 40 & 50 & \mathrm{KM}\end{array}$

Figure 2. Gravity coverage map. Black circles are the location of gravity stations prior to the start of this project. Red circles are the location of gravity stations collected for this project. The grid lines represent the boundaries of 7.5 minute USGS topographic maps. 
Preexisting gravity data, which are incorporated with the recently collected gravity data have been reprocessed using the same formulas as the new data to assure anomalies are on the same datum. These data may have had field terrain corrections, but there is no way of extracting these values from terrain corrections that were in the older data set. Inner terrain corrections were recalculated using $10 \mathrm{~m}$ DEMs from a radial distance of $68 \mathrm{~m}$ from the gravity stations to a radial distance of $2000 \mathrm{~m}$. Stations that had elevations that were more than $100 \mathrm{ft}$ different than the interpolated DEM elevations were discarded because large, and probably incorrect terrain corrections would result. The original data set had many redundant data points. These data points had the same elevations and observed gravities, but the locations were not always the same. Stations that were within 0.01 ' of latitude or longitude of another station were discarded. Outer terrain corrections and isostatic corrections were then made to the remaining stations.

\section{Data files}

Gravity data collected for this study and preexisting gravity data can be downloaded from this website in the http://pubs.usgs.gov/of/2007/1058/data/folder. The files are ASCII space-delimited and are formatted for easy insertion into a database. The new gravity data files are named new-gravity-data in both .doc and .txt format. The preexisting gravity data files are old-gravity-data in both .doc and .txt format. The gravity data files have the following format:

[FAA, free-air anomaly; SBA, simple Bouguer anomaly; CBA, complete Bouguer anomaly; ISO, isostatic anomaly]

\begin{tabular}{|c|c|c|c|c|c|c|c|c|c|c|c|c|}
\hline $\begin{array}{l}\text { Station } \\
\text { ID }\end{array}$ & $\begin{array}{l}\text { Lat } \\
\text { dec }\end{array}$ & $\begin{array}{l}\text { Eitude } \\
\text { min }\end{array}$ & $\begin{array}{l}\text { Lor } \\
\text { dec }\end{array}$ & $\begin{array}{l}\text { ngitude } \\
\text { g min }\end{array}$ & $\begin{array}{c}\text { Elevation } \\
\text { feet }\end{array}$ & $\begin{array}{l}\text { Observed } \\
\text { Gravity }\end{array}$ & $\begin{array}{l}\text { FAA } \\
\text { mGal }\end{array}$ & $\begin{array}{l}\text { SBA } \\
\text { mGal }\end{array}$ & $\begin{array}{l}\text { Terrain } \\
\text { inner }\end{array}$ & $\begin{array}{l}\text { corr. } \\
\text { total }\end{array}$ & $\begin{array}{l}\mathrm{CBA} \\
\mathrm{mGal}\end{array}$ & $\begin{array}{l}\text { ISO } \\
\text { mGal }\end{array}$ \\
\hline 4611-1 & 45 & 12.72 & 123 & 11.59 & 155.0 & 980640.36 & 16.70 & 11.41 & 0.01 & -0.03 & 11.31 & 31.48 \\
\hline FORT & 45 & 31.17 & 123 & 5.31 & 176.2 & 980596.71 & -52.79 & -58.80 & 0.01 & -0.01 & -58.89 & -36.42 \\
\hline NEWT & 45 & 18.24 & 122 & 57.00 & 202.5 & 980597.26 & -30.26 & -37.17 & 0.01 & 0.00 & -37.26 & -15.38 \\
\hline OCBA & 45 & 21.11 & 122 & 36.58 & 170.0 & 980622.69 & -12.22 & -18.02 & 0.57 & 0.52 & -17.57 & 13.67 \\
\hline $\mathrm{R} 14$ & 45 & 31.50 & 122 & 40.64 & 30.0 & 980632.79 & -30.96 & -31.98 & 0.03 & 0.08 & -31.91 & -4.57 \\
\hline STHB & 45 & 51.14 & 122 & 49.71 & 98.5 & 980650.93 & -36.00 & -39.35 & 0.03 & 0.03 & -39.36 & -11.87 \\
\hline TROB & 45 & 32.24 & 122 & 25.21 & 135.5 & 980613.90 & -41.04 & -45.66 & 0.08 & 0.13 & -45.59 & -7.49 \\
\hline
\end{tabular}

Also available on this website is a 1:250,000 scale map of the gridded isostatic anomalies shown as a color map (http://pubs.usgs.gov/of/2007/1058/of2007-1058_gravity-map.pdf) with a contour interval of 4 milligals. As with figure 2, this map shows new gravity stations in red and preexisting gravity stations shown in black. It also shows the boundaries of the 7.5' quadrangles, but also includes the quadrangle names. In addition, a set of faults by Yeats and others (1996) is shown, many of which correlate with gravity gradients or anomalies. Printing this map at a scale of 1:250,000 requires a largeformat (24-36 inch) plotter.

Base station descriptions are also located on the website in the http://pubs.usgs.gov/of/2007/1058/data/folder. Those .pdf files are named: base-station-desc-FORESTGROVE.pdf, base-station-desc-McMINNVILLE.pdf, base-station-desc-NEWBERG.pdf, base-stationdesc-OREGON-CITY.pdf, base-station-desc-PORTLAND-R14.pdf, base-station-desc-ST.HELENS.pdf, and base-station-desc-TROUTDALE.pdf.

\section{References Cited}

Barnes, D. F., Oliver, H.W., and Robbins, S.L., 1969, Standardization of gravimeter calibrations in the Geological Survey: Eos (American Geophysical Union Transactions), v. 50, no. 10, p. 626-527. Hayford, J.F., and Bowie, William, 1912, The effect of topography and isostatic compensation upon the intensity of gravity: U.S. Coast and Geodetic Survey Special Publication no. 10, 132 p. 
International Association of Geodesy, 1971, Geodetic reference system 1967: International Association of Geodesy Special Publication No. 3, 116 p.

Jachens, R.C., and Roberts, C.W., 1981, Documentation of a FORTRAN program, 'isocomp', for computing isostatic residual gravity: U.S. Geological Survey Open-File Report 81-574, 26 p.

Karki, Pentti, Kivioja, Lassi, and Heiskanen, W.A., 1961, Topographic isostatic reduction maps for the world for the Hayford Zones 18-1, Airy-Heiskanen System, T=30 km: Publication of the Isostatic Institute of the International Association of Geodesy, no. 35, 5p., 20 pl.

Morelli, C., ed., 1974, the International gravity standardization net 1971: International Association of Geodesy Special Publication no. 4, 194 p.

Plouff, Donald, 1977, Preliminary documentation for a FORTRAN program to compute gravity terrain corrections based on topography digitized on a geographic grid: U.S. Geological Survey OpenFile Report 77-535, $45 \mathrm{p}$.

Swick, C.H., 1942, Pendulum gravity measurements and isostatic reductions: U.S. Coast and Geodetic Survey Special Publication no. 232, 82 p.

Yeats, R.S., Graven, E.P., Werner, K.S., Goldfinger, C., and Poposki, T.A., 1996, Tectonics of the Willamette Valley, Oregon, in Rogers, A.M., and others, eds., Assessing earthquake hazards and reducing risk in the Pacific Northwest: U.S. Geological Survey Professional Paper 1560, p. 183222. 